\title{
Impact of chlorpyrifos toxicity on gill damage of two species of freshwater fish in Lake Diatas
}

\author{
Tivany Edwin* $^{(\mathbb{}}$, Taufiq Ihsan $^{\circledR}$, Aufa Rahmatika ${ }^{\circledR}$, Nanda Darlis ${ }^{\circledR}$ \\ Department of Andalas University, Kampus Unand Limau Manis Padang 25163, West Sumatera , Indonesia
}

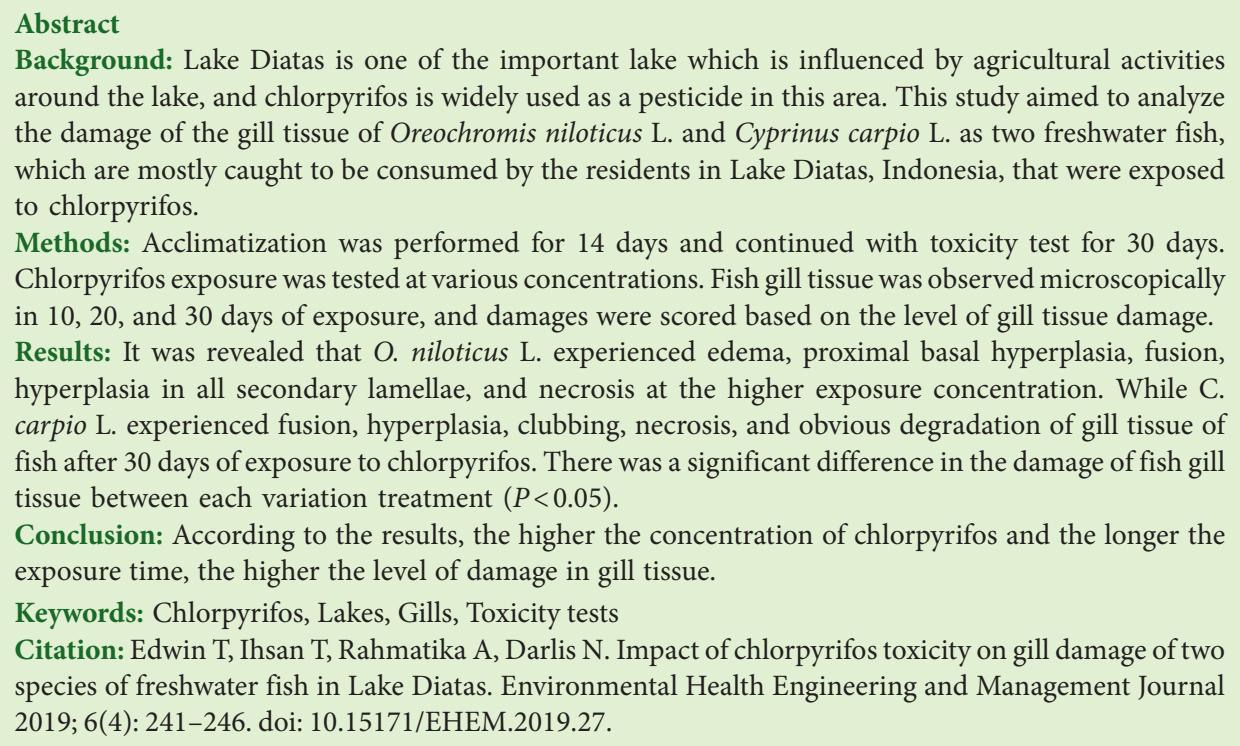
around the lake, and chlorpyrifos is widely used as a pesticide in this area. This study aimed to analyze the damage of the gill tissue of Oreochromis niloticus L. and Cyprinus carpio L. as two freshwater fish, which are mostly caught to be consumed by the residents in Lake Diatas, Indonesia, that were exposed to chlorpyrifos.

Methods: Acclimatization was performed for 14 days and continued with toxicity test for 30 days. Chlorpyrifos exposure was tested at various concentrations. Fish gill tissue was observed microscopically in 10, 20, and 30 days of exposure, and damages were scored based on the level of gill tissue damage. Results: It was revealed that $O$. niloticus L. experienced edema, proximal basal hyperplasia, fusion, hyperplasia in all secondary lamellae, and necrosis at the higher exposure concentration. While C. carpio L. experienced fusion, hyperplasia, clubbing, necrosis, and obvious degradation of gill tissue of fish after 30 days of exposure to chlorpyrifos. There was a significant difference in the damage of fish gill tissue between each variation treatment $(P<0.05)$.

Conclusion: According to the results, the higher the concentration of chlorpyrifos and the longer the exposure time, the higher the level of damage in gill tissue.

Keywords: Chlorpyrifos, Lakes, Gills, Toxicity tests

Citation: Edwin T, Ihsan T, Rahmatika A, Darlis N. Impact of chlorpyrifos toxicity on gill damage of two species of freshwater fish in Lake Diatas. Environmental Health Engineering and Management Journal 2019; 6(4): 241-246. doi: 10.15171/EHEM.2019.27.

\section{Article History:} Received: 22 May 2019 Accepted: 4 September 2019 ePublished: 6 October 2019

\section{Introduction}

Lake Diatas is a lake located in Nagari Alahan Panjang, Lembah Gumanti sub-district, Solok district, West Sumatera province, Indonesia. It is classified as tectonic lake with maximum depth of $44 \mathrm{~km}$ and $12.3 \mathrm{~km}^{2}$ area. The water source of Lake Diatas comes from the Aie Mati River and the Batang Galagah River, while the water comes out through the estuary into the Batang Gumanti River. The lake is one of the potential resources, especially in the field of tourism and agriculture, which improving the economy of the people who live around it. Lake Diatas is used by residents for daily living, water transportation for surrounding residents, as well as for other activities like fishing. The geographical map of Lake Diatas can be seen in Figure 1.

Oreochromis niloticus L. and Cyprinus carpio L. are two fish, which are widely cultivated as fresh water fish in Lake Diatas. These fish are economical, widely consumed by the society, and can show reaction to environmental changes. C. carpio L. lives in fresh water that is not too deep and the flow is not too heavy, like on the banks of rivers or lakes. This fish can live well in areas with an altitude of 150-600 m above sea level and at a temperature of $25-30^{\circ} \mathrm{C}$. Although it is classified as freshwater fish, it is occasionally found in brackish waters or river estuaries of $25 \%-30 \%$ salinity. C. carpio L. can survive at a low dissolved oxygen (DO) concentration of $0.3-0.5 \mathrm{mg} / \mathrm{L}(1,2)$.

While $O$. niloticus $\mathrm{L}$. has the ability to grow normally at temperature between 14 and $38^{\circ} \mathrm{C}$ with the optimum temperature for growth is $25-30^{\circ} \mathrm{C}$. The optimum $\mathrm{pH}$ for the growth of the fish is $7-8$ and the fish body color is affected by the environment. This fish should live in water with dissolved oxygen levels greater than $3 \mathrm{mg} / \mathrm{L}(2,3)$. The use of pesticides in the West Sumatra region is dominated by organophosphate pesticides, which are very toxic and have a half-life that varies in nature. The main type of organophosphate pesticides that are often used in West Sumatera is chlorpyrifos. Chlorpyrifos is also widely used for the agricultural activities around Lake Diatas. Small amounts of chlorpyrifos can have significant effect 


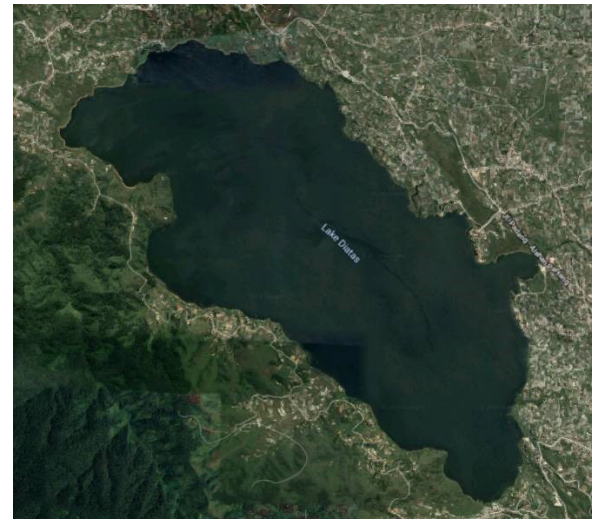

Figure 1. Geographical map of Lake Diatas, Indonesia.

due to its nature, because it cannot be mixed well with water, and therefore, remain on the surface of the water with air and evaporate (4).

The respiratory system of fish consists of organs that bind oxygen and emit carbon dioxide. These organs are gills and gill-related structures, such as blood vessels allowing the exchange of oxygen and carbon dioxide. The gills have branched structures wrapped entirely by the outer layers and are composed of thin-walled filaments or lamellae, each having a blood capillary. Therefore, gill is the primary and vital respiratory organ in fish (5).

If fish is exposed to environmental pollutants, such as pesticides, its important function will be in danger due to the disruption of oxygen uptake of fish, which will indirectly affect the growth of fish. The structure of gill tissue composed of thin epithelium, which can be directly in contact with toxic substances in the environment (6). Damage to gill tissue can be investigated by analyzing histopathological changes in this tissue, such as edema (swelling of tissue), fusion (an increase in the number of cells in the tissue), hyperplasia (increased cell production), and necrosis (death of cell). Edema is swelling of tissue, fusion is marked with thickening of epidermis, hyperplasia is the enlargement of an organ or tissue caused by an increase in the reproduction rate of its cells, and necrosis is a form of cell injury, which results in the premature death of cells in living tissue (6).

The aim of this study was to analyze the histopathological changes in gill tissue of $O$. niloticus $L$. and C. carpio L., which was exposed to chlorpyrifos insecticide at various concentrations.

\section{Materials and Methods}

Fish maintenance

Oreochromis niloticus L. and C. carpio L. juveniles were obtained from Sungai Bangek, Kecamatan Lubuk Minturun Padang. The characteristics of O. niloticus L. (initial length: $4-5 \mathrm{~cm}$, body weight: $2-2.5 \mathrm{~g}$, and age: \pm 1 month) and C. carpio L. (initial body length: $\pm 7-8 \mathrm{~cm}$, body weight: $\pm 5 \mathrm{~g}$, age: about \pm 3 months), considering the size of the gill for the sample preparation purposes, were measured. Fish were used in experiments after being acclimated in a holding tank for 14 days. Fish were fed with pellet (brand PF 80) three times a day. The water in the fish tanks was replaced every three to four days, according to the renewal test method (7). Acclimatization was performed to adapt fish to environmental conditions, which maintained by the measurement of temperature, $\mathrm{pH}$, and DO. The acclimatization was successful if no more than $3 \%$ of the test animals died within 48 hours. The acclimatization of test animals in this study was conducted for 14 days (8).

\section{Experimental setup}

In this study, glass fish tanks $(45 \times 40 \times 40 \mathrm{~cm})$ equipped with an aerator with $3.5 \mathrm{~L} / \mathrm{min}$ discharge were used $(9,10)$. Chlorpyrifos insecticide solution used in this study was Dursban 200 EC. The water volume for each tank was adjusted to the ratio of $1 \mathrm{~L}$ of water for $0.8 \mathrm{~g}$ of fish weight (8). Each variation was carried out in 3 fish tanks, each containing 20 fish (11). The fish were observed for their gill tissue damages every 10 days until day 30 .

Sublethal toxicity test was performed using an artificial solution of chlorpyrifos insecticide. O. niloticus L. was exposed to chlorpyrifos at concentrations of 0.0019 , 0.0038 , and $0.0076 \mathrm{mg} / \mathrm{L}$. While C. carpio L. was exposed to chlorpyrifos at concentrations of $0.0007,0.0014$, and $0.0028 \mathrm{mg} / \mathrm{L}$. Control group containing only chlorine-free water.

The gills were taken from 3 fish samples of each test variation every 10 days. The fish were anesthetized using frozen ice, and then, the gills were taken and fixed with Bouin's solution, and followed by hematoxylin and eosin (H \& E) method. Microscopic observations of histological gill slice preparation were performed using a microscope with 40-1000X magnification for histopathological analysis.

\section{Gill scores}

The gill damages were analyzed using a semi-quantitative scoring system, and scored from $0-5$ based on the presence of edema (swelling of tissue), hyperplasia (increased cell production), lamellar fusion (increased number of cells in the tissue), and necrosis (death of cell) (12). Observations were assessed using scoring methods based on the extent of tissue damage, as presented in Table 1.

\section{Statistical analysis}

The scores of gill tissue damage were calculated, and the mean score was then analyzed with regression and correlation analysis to determine the relationship of gill damage with chlorpyrifos concentration and duration of exposure. Kruskal-Wallis test was conducted to determine if there is a significant difference between each variance, the calculations continued with Mann-Whitney $U$ test at $5 \%$ level of significance to determine the real difference between gill damage at each concentration and duration 
Table 1. Level of gill tissue damages

\begin{tabular}{lll}
\hline Level & Score & Details \\
\hline I & 1 & There is edema in the lamellae and the release of epithelial cells from the underlying tissue; \\
II & 2 & Occurrence of hyperplasia in the secondary proximal basal lamellae; \\
III & 3 & Hyperplasia in the two secondary lamellae and clubbing; \\
IV & 4 & Hyperplasia occurs almost in all parts of the lamellae \\
V & 5 & There is a loss of secondary lamellar structure and filament damage. \\
\hline
\end{tabular}

exposure. The data were analyzed using Kruskal-Wallis and Mann-Whitney U tests by SPSS version 20 .

\section{Results}

Water quality during toxicity test was suitable for both fish species. Measurement of $\mathrm{pH}$ ranged 7.5-8.5 for O. niloticus L. and 7.9-8.3 for C. carpio L. While DO concentration ranged 6.6-7.6 mg/L for $O$. niloticus $\mathrm{L}$. and 5.3-7.3 for $C$. carpio L., with the requirement for DO was larger than 3 $\mathrm{mg} / \mathrm{L}$. The temperature of water for fish ranged 25, 1-28, and $8^{\circ} \mathrm{C}$ for O. niloticus L. and $25.6-28.5^{\circ} \mathrm{C}$ for C. carpio L., with the requirement for both fish ranging $25-30^{\circ} \mathrm{C}$.

Gill tissue damage of Oreochromis niloticus L.

The damages of the gill tissue of $O$. niloticus L. are shown in Table 2. The damages of the gill tissue of control samples slightly increased every 10 days. It was revealed that control group experienced some minor damages of edema and hyperplasia, which were considered standard for farmed fish (13).

The worst gill lesion of necrosis was observed in the fish exposed to $0.0076 \mathrm{mg} / \mathrm{L}$ of chlorpyrifos, which can be seen in Table 2. In the exposure of $0.0019 \mathrm{mg} / \mathrm{L}$ chlorpyrifos, gill experienced edema and fusion, while in the exposure of $0.038 \mathrm{mg} / \mathrm{L}$ chlorpyrifos, gill experienced hyperplasia. Increasing scores of damages by the higher and longer chlorpyrifos exposure are presented in Figure $2(P<0.05)$.

\section{Gill tissue damages of Cyprinus carpio L.}

Damages of the gill tissue of C. carpio L. can be seen in Table 3. Similar to O. niloticus L., there was a slight damage to gill tissue of $C$. carpio as control group, which

Table 2. Gill tissue damages of Oreochromis niloticus in 30 days of exposure to chlorpyrifos

\begin{tabular}{|c|c|c|c|}
\hline \multirow{2}{*}{$\begin{array}{l}\text { Chlorpyrifos } \\
\text { Concentration }\end{array}$} & \multicolumn{3}{|c|}{ Changes in Gill Tissue of Oreochromis niloticus } \\
\hline & Day-10 & Day-20 & Day-30 \\
\hline \multicolumn{4}{|l|}{ Control group } \\
\hline \multicolumn{4}{|l|}{$0.0019 \mathrm{mg} / \mathrm{L}$} \\
\hline \multicolumn{4}{|l|}{$0.0038 \mathrm{mg} / \mathrm{L}$} \\
\hline \multicolumn{4}{|l|}{$0.0076 \mathrm{mg} / \mathrm{L}$} \\
\hline
\end{tabular}




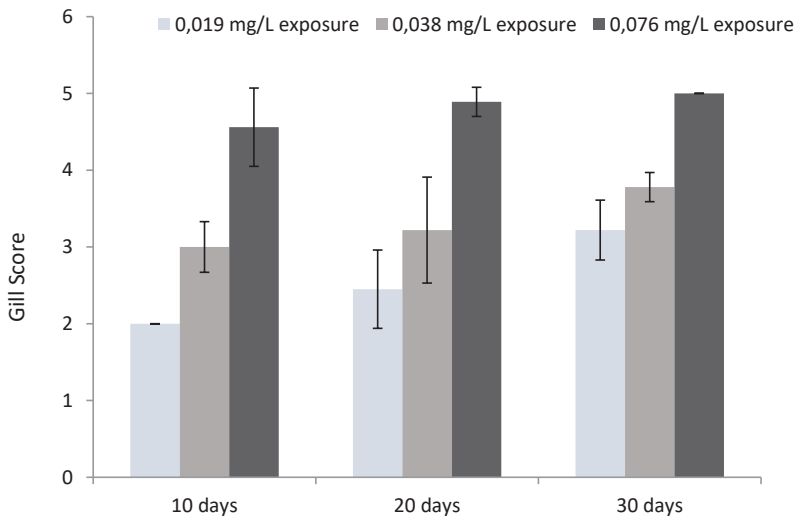

Figure 2. Gill tissue damages of Oreochromis niloticus by score.

were considered normal for farmed fish (13).

The higher score by the longer exposure to higher chlorpyrifos concentrations, was supported by $P<0.05$. The gill experienced fusion and hyperplasia after 30 days of exposure to $0.0019 \mathrm{mg} / \mathrm{L}$ chlorpyrifos. While in the exposure to $0.038 \mathrm{mg} / \mathrm{L}$ chlorpyrifos, gill experienced hyperplasia since the $10^{\text {th }}$ day of experiment. Necrosis of gill tissue was observed in the exposure to $0.0076 \mathrm{mg} / \mathrm{L}$ chlorpyrifos.
At concentration of $0.0007 \mathrm{mg} / \mathrm{L}$, the gill of fish experienced the changes by the occurrence of fusion to hyperplasia throughout lamellae within 30 days of exposure. On the 10th and 20th days, the gills of fish experienced fusion in the form of the binding of the two secondary lamellae. According to Robert, fusion occurs due to an increase in the number of mucus cells in the lamellae that continuously increases (6). On the 20th day, lamellae fusion was more prevalent in the gill tissue of $C$. carpio L. compared to that on the 10th day. And on the 30th day, the gills of fish experienced a complete lamellae hyperplasia, characterized by the incorporation of several secondary lamellae throughout the lamellae (Figure 3).

\section{Discussion}

The results showed that chlorpyrifos is responsible for pathological changes in the fish gill. In a similar study by Pal et al, the effects of chlorpyrifos on the gill of Cyprinus carpio for 14 days were investigated and several damages to gill, including fusion, hyperplasia to necrosis, were reported (14). Another study by Xing et al also showed histopathological changes in the brain and kidney of common carp after 40 days of exposure with more severe damages at higher exposure doses (15).

Table 3. Gill tissue damages of Cyprinus carpio in 30 days of exposure to chlorpyrifos

\begin{tabular}{|c|c|c|c|}
\hline Chlorpyrifos & & ssue of & \\
\hline Concentration & Day 10 & Day 20 & Day 30 \\
\hline Control group & & & \\
\hline $0.0007 \mathrm{mg} / \mathrm{L}$ & & & \\
\hline $0.0014 \mathrm{mg} / \mathrm{L}$ & & & \\
\hline $0.0028 \mathrm{mg} / \mathrm{L}$ & & & \\
\hline
\end{tabular}




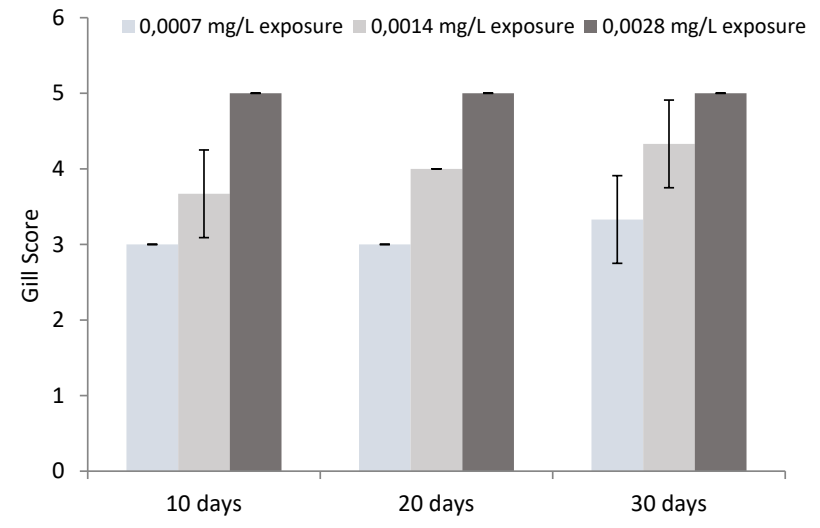

Figure 3. Gill tissue damages of Cyprinus carpio $L$ by score.

According to a study by Harper and Wolf, stress response in fish can be detected early through observation of behavioral changes, anatomical pathology examination, and histopathology of several organs or tissues, such as gills (16). Stress in fish can affect the damage to gill cells, such as edema, hyperplasia, and cell fusion. Something that disrupts the energy metabolism in the cell or slightly injures the cell membrane can make the cell unable to pump sodium ions. As a result, the osmotic pressure caused by the increase of sodium concentration possibly makes the water diffuse into the cell in the form of morphological changes, called edema or cell swelling (6). Fusion of the secondary lamellae results in the disruption of the oxygen-taking process by the gills. Another study by Efrizal et al also showed fusion damage in gill tissue of indigo fish caused by phosphamidon insecticide (17). Hyperplasia in the proximal basal and fusion of secondary lamellae are chronic reactions due to irritation by chemicals. In the study of Qureshi et al, carp was used as a test animal and exposed to $0.2 \mathrm{mg} / \mathrm{L}$ fipronil and 0.05 $\mathrm{mg} / \mathrm{L}$ buprofezin insecticides, and hyperplasia throughout the secondary lamellae was reported (18). According to Gomes et al, fusion is caused by environmental factors, aquatic pollutants, the intensity of the interaction of biotic organisms, and the limitations of food preparation (19). Based on the above statement, the occurrence of fusion and hyperplasia throughout the secondary lamellae in this study is due to these environmental factors, because apart from the chlorpyrifos exposure, fish interactions and the limitations of food preparation could also be the other causes of these changes.

The occurrence of necrosis in this study was caused by the absorption of chlorpyrifos through the gills, which inhibits gill function as a respiratory device and ultimately lead to death of fish. Consistent with this study, Durham reported that toxic compounds inhibits cell metabolism, so that no more energy can be formed for survival (9). Similarly, Rennika et al found that the exposure of gill tissue of O. mossambicus to diazinon with $2.5 \%$ concentration of LC50 (0.00625 mg/L) caused histopathological changes including edema, hyperplasia in proximal basal, and fusion (11).

\section{Conclusion}

The damages to the gill tissue of $O$. niloticus $\mathrm{L}$. and $C$. carpio $\mathrm{L}$. were observed in all variations within 30 days of exposure to various concentration of chlorpyrifos. The gill tissue of O. niloticus L., at experienced proximal basal edema and hypeprlasia in no exposure of chlorpyrifos, at $0.0019 \mathrm{mg} / \mathrm{L}$ chlorpyrifos concentration experienced proximal basal hypeprlasia and fusion, at $0.0038 \mathrm{mg} / \mathrm{L}$ concentration experienced hyperplasia in all secondary lamellae, and at $0.0076 \mathrm{mg} / \mathrm{L}$ concentration experienced necrosis.

While the gill tissue of $C$. carpio L., at chlorpyrifos concentration of $0.0007 \mathrm{mg} / \mathrm{L}$ experienced fusion and hyperplasia throughout the lamellae. At exposure of $0.0014 \mathrm{mg} / \mathrm{L}$ chlorpyrifos, clubbing of gill tissue and hyperplasia throughout the lamellae were observed, while necrosis was observed in gill tissue at exposure of 0.0028 $\mathrm{mg} / \mathrm{L}$ chlorpyrifos.

Statistical analysis of the results of Kruskal-Wallis and Mann-Whitney tests showed a significant difference between the longer exposure time and the higher concentration of chlorpyrifos exposure, which resulted in the higher histopathological changes of the gill tissue. Further research can be conducted on the effect of longterm exposure to chlorpyrifos on the histopathological changes in other tissues and also to determine the effect on the behavioural changes and fish survival.

\section{Acknowledgements}

This study was extracted from a thesis conducted in the Department of Environmental Engineering and also Laboratory of Animal Development Structure of the Faculty of Mathematics and Natural Sciences of Andalas University. The authors would like to gratitude Andalas University for its assistance.

\section{Ethical issues}

The authors hereby certify that all data collected during the study are as stated in the manuscript, and no data from the study has been or will be published separately elsewhere.

\section{Competing interests}

The authors declare that they have no competing interests.

\section{Author's contribution}

The authors contributed and were equally involved in the suggestion of the problem, design of experiments, data collection, and article approval.

\section{References}

1. FAO. Cultured aquatic species fact sheets. [cited 2019 Dec 1) Available from: http://www.fao.org/tempref/FI/ DOCUMENT/aquaculture/CulturedSpecies/file/en/en_ 
commoncarp.htm.

2. CABI. Invasive Species Compendium. [cited 2019 Nov 11] Available from: https://www.cabi.org/isc/datasheet/72086\# towaterTolerances.

3. Wahyu Wiryanto BT, Sunaryo SP, Astuti SP, Kurniawan MB. Buku Pintar Budi Daya \& Bisnis Ikan Nila. Jakarta; AgroMedia Pustaka; 2010. [In Bahasa Indonesia].

4. Agency for Toxic Substances and Disease Registry (ATSDR). Toxycology Profile for Chlorpyrifos. US: Department of Health and Human Services; 2000.

5. Ersa IM. Gambaran Histopatologi Insang, Usus dan Otot pada Ikan Mujair (Oreochromis mossambicus) di Daerah Ciampea Bogor. Bogor: Faculty of Veterinary Medicine Bogor Agricultural Institute; 2008. [In Bahasa Indonesia].

6. Robert RJ. Fish Pathology. Journal of Fish Diseases 2002; 25(2): 125.

7. Thophon S, Kruatrachue M, Upatham ES, Pokethitiyook P, Sahaphong S, Jaritkhuan S. Histopathological alterations of white seabass, Lates calcarifer, in acute and subchronic cadmium exposure. Environ Pollut 2003; 121(3): 307-20. doi: 10.1016/s0269-7491(02)00270-1.

8. American Public Health Association (APHA), American Water Works Association (AWWA), Water Environment Federation (WEF). Standard Methods for the Examination of Water and Wastewater. 22nd ed. Washington DC: APHA; 2014.

9. Durham T. Toksikologi Lingkungan. Yogyakarta: UGM Press; 1995. [In Bahasa Indonesia].

10. Edwin T, Ihsan T, Putra MA, Guspariani. acute and sublethal toxicity test on Oreochromis niloticus exposed with tannery wastewater. Int J Adv Res 2018; 6(5): 742-8. doi: 10.21474/IJAR01/7091.

11. Rennika, Aunurohim, Abdulgani N. Konsentrasi dan lama pemaparan senyawa organik dan inorganik pada jaringan insang ikan mujair (Oreochromis mossambicus) pada kondisi sub lethal. Jurnal Sains Dan Seni Pomits 2013; 2(2): E132-7. [In Bahasa Indonesia].

12. Windarti TE, Chaidir P, Deni E, Yulianti. Fisiologi Hewan Air. Pekanbaru: Faculty of Fisheries and Marine Science Riau University; 2010. [In Bahsa Indonesia].

13. Steckert LD, Cardoso L, Jerônimo GT, Pádua SB, Martins ML. Investigation of farmed Nile tilapia health through histopathology. Aquaculture 2018; 486: 161-9. doi: 10.1016/j.aquaculture.2017.12.021.

14. Pal S, Kokushi E, Koyama J, Uno S, Ghosh AR. Histopathological alterations in gill, liver and kidney of common carp exposed to chlorpyrifos. J Environ Sci Health B 2012; 47(3): 180-95. doi: 10.1080/03601234.2012.632285.

15. Xing $\mathrm{H}, \mathrm{Li} S$, Wang $\mathrm{Z}$, Gao $\mathrm{X}, \mathrm{Xu} \mathrm{S}$, Wang $\mathrm{X}$. Histopathological changes and antioxidant response in brain and kidney of common carp exposed to atrazine and chlorpyrifos. Chemosphere 2012; 88(4): 377-83. doi: 10.1016/j.chemosphere.2012.02.049.

16. Harper C, Wolf JC. Morphologic effects of the stress response in fish. ILAR J 2009; 50(4): 387-96. doi: 10.1093/ ilar.50.4.387.

17. Efrizal T, Setijanto H, Lumbanbatu DT, Sukra Y. The effect of sublethal concentration of phosphamidon on tissue damage of Nile fish. [cited 2019 Dec 1] Available from: https://repository.ipb.ac.id/handle/123456789/56756.

18. Qureshi IZ, Bibi A, Shahid S, Ghazanfar M. Exposure to sub-acute doses of fipronil and buprofezin in combination or alone induces biochemical, hematological, histopathological and genotoxic damage in common carp (Cyprinus carpio L.). Aquat Toxicol 2016; 179: 103-14. doi: 10.1016/j.aquatox.2016.08.012.

19. Gomes ID, Nascimento AA, Sales A, Araujo FG. Can fish gill anomalies be used to assess water quality in freshwater neotropical systems? Environ Monit Assess 2012; 184(9): 5523-31. doi: 10.1007/s10661-011-2358-2. 